\title{
Spontaneous and induced immunoglobulin secretion by synovial fluid B lymphocytes in rheumatoid arthritis
}

\author{
JØRGEN PETERSEN, THORSTEN INGEMANN-HANSEN, AND \\ JENS HALKJÆR-KRISTENSEN
}

From the Laboratory of Medical Immunology, Department of Medicine TA, the Rigshospital University Hospital, Copenhagen, and the Department of Rheumatology, Hvidovre University Hospital, Denmark

SUMmARY The functional properties of B lymphocytes in synovial fluid (SF) from patients with rheumatoid arthritis (RA) were analysed by means of a reverse haemolytic plaque forming cell (PFC) assay. SF mononuclear cells spontaneously secreted IgG, but little IgM or IgA. The SF cells failed to respond to the polyclonal $B$ cell activators pokeweed mitogen (PWM) and Epstein-Barr virus. However, SF B cells cocultured with autologous T lymphocytes from the blood and stimulated with PWM secreted IgG but little IgM or IgA. The PFC responses of blood B cells cocultured with autologous SF T cells in the presence of PWM were low; irradiation of the T cells increased the blood B lymphocyte responses, but the differences were not statistically significant. It is concluded that suppressor SF T cells may be partly responsible for the poor response of SF B cells to PWM.

In recent years evidence has been provided for the participation of both antibody-mediated ${ }^{12}$ and cellmediated ${ }^{3}{ }^{4}$ immune reactions in rheumatoid arthritis (RA). By the development of sensitive assays for quantitation of human B lymphocyte activation in vitro it has been shown that at least 2 cell populations regulate $\mathrm{B}$ cell function. Monocytes/macrophages $(\mathrm{M} \varphi)$ are mandatory for the B lymphocyte response to polyclonal B cell activators such as pokeweed mitogen (PWM) ${ }^{5}$ and Staphylococcus aureus. ${ }^{6}$ When present in high concentrations, $\mathrm{M} \varphi$ s suppress the responses of B cells. ${ }^{6}$ Suppression is furthermore achieved with smaller amounts of $M \varphi s$ stimulated in vitro. ${ }^{7}$ Besides $\mathrm{M} \varphi \mathrm{s}$, $\mathrm{T}$ lymphocytes subsets-that is, $\mathrm{T}$ helper and $\mathrm{T}$ suppressor cells, are significant for modulation of the B cell differentiation. ${ }^{8}$

In the synovial fluid (SF) of RA patients T lymphocytes and $\mathrm{M} \varphi$ s are found in considerable numbers, ${ }^{9}{ }^{10}$ whereas few B lymphocytes have been demonstrated..$^{9}$ According to recent investigations ${ }^{11}$ synovial fluid $\mathrm{T}$ cells comprise more cells with suppressor phenotype as determined by monoclonal antibodies than are found in the blood. However, the functional implication of the increased proportions of $\mathrm{T}$ cells

Accepted for publication 7 April 1983.

Address for correspondence: Jørgen Petersen, MD, Laboratory of Medical Immunology TA 7544, Rigshospitalet University Hospital, 20 Tagensvej, 2200 Copenhagen N, Denmark. with the morphological characteristics of suppressor cells remains to be clarified.

The aims of the present investigation are to evaluate the ability of synovial fluid B cells from RA patients to secrete immunoglobulins (Ig) spontaneously, to investigate the responses of synovial fluid B cells to polyclonal activators, and finally to assess the influence of synovial fluid $\mathrm{T}$ lymphocytes on the function of autologous blood B cells.

\section{Materials and methods}

Patients. Eight patients, mean age 48 years (range 36 to 69 years), with definite or classical RA according to the American Rheumatism Association criteria were included in the study. Four patients were receiving gold salts, 2 patients penicillamine, and 1 patient prednisone (in a dose of $10 \mathrm{mg}$ daily) at the time of the study. All the patients were treated with nonsteroidal anti-inflammatory drugs.

From all the patients synovial fluid free of blood was obtained by puncture of the knee. A blood specimen was drawn on the same day.

Isolation of mononuclear cells. Mononuclear cells from blood (BMC) and from synovial fluid (SMC) were isolated by centrifugation on Lymphoprep (Nyegaard, Oslo, Norway) as described previously. ${ }^{10} \mathrm{BMC}$ and SMC were washed and resus- 
pended in Roswell Park Memorial Institute (RPMI) solution 1640 (Gibco, Paisley, Scotland), supplemented with penicillin $(500 \mathrm{IU} / \mathrm{ml})$, streptomycin $(500 \mu \mathrm{g} / \mathrm{ml})$, L-glutamine $(0.8 \mathrm{mM})$, and $10 \%$ fetal calf serum (FCS) (Flow, Irvine, Scotland).

BMC contained $71 \pm 5 \%$ E-rosetting cells (mean \pm 1 SEM), $9 \pm 4 \%$ surface membrane immunoglobulin (SMIg)-positive cells as determined by fluorescein-isothiocynate-conjugated antihuman $\mu$, $\gamma, \alpha, \kappa$, and $\lambda$ chains (Dako, Copenhagen, Denmark), and $17 \pm 5 \% \mathrm{M} \varphi \mathrm{s}$ as judged by staining for $\alpha$-naphthyl acetate esterase activity. ${ }^{12}$ SMC comprised $64 \pm 8 \%$ E-rosetting cells, $3 \pm 1 \%$ SMIgpositive cells, $24 \pm 7 \% \mathrm{M} \varphi \mathrm{s}$ and $6 \pm 2 \%$ polymorphonuclear cells (PMN). ${ }^{10}$

Isolation of T-depleted, T-enriched, MØ-depleted and $M \varphi$-enriched suspensions. $3 \mathrm{ml}$ of BMC and SMC $\left(3 \times 10^{6} / \mathrm{ml}\right)$ were incubated with an equal volume of sheep red blood cells (SRBC) treated with 2amino-ethyl-iso-thiouronium (AET) (Sigma, St Louis, Missouri, USA) ${ }^{13} 1 \%$ in RPMI 1640 with $40 \% \mathrm{FCS}$, for $30 \mathrm{~min}$ at $37^{\circ} \mathrm{C}$. The mixture was then centrifuged for $5 \mathrm{~min}$ at $72 \mathrm{~g}$, resuspended, and centrifuged for $30 \mathrm{~min}$ on Lymphoprep. T-depleted cells were harvested from the interphase and washed 3 times. The rosetted T-enriched cells were exposed to $\mathrm{NH}_{4} \mathrm{Cl}$, and, after lysis of AET-SRBC, the cells were washed 3 times. Half of the $T$-enriched cells were irradiated $(2500 \mathrm{rad})$ in a ${ }^{60} \mathrm{Co}$ source $(600 \mathrm{rad} / \mathrm{min})$.

T-depleted cells from the blood contained $2 \pm 1 \%$ E-rosetting cells, $56 \pm 12 \%$ SMIg-positive cells, and $28 \pm 7 \% \mathrm{M} \varphi$ s. Among T-depleted SF cells $2 \pm 1 \%$ E-rosetting cells, $39 \pm 14 \%$ SMIg-positive cells, $35 \pm$ $9 \% \mathrm{M} \emptyset \mathrm{s}$, and $20 \pm 4 \%$ PMN were found.

T-enriched cells from blood comprised $83 \pm 6 \%$ E-rosetting cells, $1 \pm 1 \%$ SMIg-positive cells, and 1 $\pm 1 \% \mathrm{M} \varphi \mathrm{s}$. In the case of T-enriched cells from synovial fluid the proportion of T-cells was higher: 87 $\pm 8 \%$ E-rosetting cells, $0.5 \pm 1 \%$ SMIg-positive cells, and $1 \pm 1 \% \mathrm{M} \varphi \mathrm{s}$.

$\mathrm{M} \varphi$-depleted SMC were obtained by decanting nonadherent cells as described previously. ${ }^{7} \mathbf{M} \varphi$ enriched cells were isolated by incubating adherent cells with EDTA $(10 \mathrm{mM}){ }^{7} \mathrm{M} \varphi$-depleted and $\mathrm{M} \varphi$ enriched SMC contained on the average $1.1 \%$ and $75 \%$ respectively.

Viability of T-depleted, T-enriched, $\mathrm{M} \varphi$-depleted, and $\mathbf{M} \varphi$-enriched cells from blood or synovial fluid always exceeded $95 \%$, as determined by nigrosin exclusion.

Generation of PWM- and EBV-induced PFC responses. BMC, SMC, or mixtures of subpopulations of mononuclear cells were cultured at $1.0 \times$ $10^{6} / \mathrm{ml}$ in flat-bottomed microtitre plates (Nunc, Roskilde, Denmark), $250 \mu \mathrm{l}$ per well. ${ }^{7}$ Culture medium was RPMI supplemented with antibiotics,
L-glutamine, $10 \%$ FCS, and nystatin $(20 \mathrm{U} / \mathrm{ml})$. Mixtures of cells were always made with viable cells. Only autologous cell mixtures were used. PWM (Gibco) was added at the onset of culture at $0.8 \mu \mathrm{g} / \mathrm{ml}$. In some experiments $2 \times 10^{6}$ cells were exposed to $1 \mathrm{ml}$ of Epstein-Barr virus (EBV)-containing supernatant from a B95-8 marmoset lymphoblastoid cell line ${ }^{14}$ for $2 \mathrm{~h}$ at $37^{\circ} \mathrm{C}$ and washed twice prior to culture.

Cells were cultured for 6 days at $37^{\circ} \mathrm{C}$ in a humidified atmosphere consisting of $95 \%$ air and $5 \%$ carbon dioxide. At harvest the cells were collected and washed once in minimum essential medium (MEM) (Flow) prior to performance of the plaque forming cell (PFC) assay.

Quantitation of Ig-secreting cells. This was carried out by a reverse haemolytic PFC assay. ${ }^{15}{ }^{16}$ In brief Staphylococcus aureus protein A (SPA) (Pharmacia, Uppsala, Sweden) was conjugated to SRBC by the chromium chloride method. ${ }^{17}$

The following reagents were all diluted in MEM. $100 \mu \mathrm{l}$ cells, either freshly isolated (washed once in MEM) or cultured for 6 days as described above, SPA-SRBC, guinea-pig complement, and antihuman IgM, IgG, or IgA (Dako) were mixed with agar (Noble, Difco, Detroit, Michigan, USA) supplemented with diethyl aminoethyl dextran (Pharmacia) at $45^{\circ} \mathrm{C}^{16}$ Three drops of $200 \mu$ l were placed in $9 \mathrm{~cm}$ Petri dishes (Nunc) and covered with slips. The preparations were incubated for $4 \mathrm{~h}$ at $37^{\circ} \mathrm{C}$, and plaques were read at 10 times magnification by indirect light. The number of PFC was calculated per $10^{6}$ live cells (in the case of spontaneous PFC) or per $10^{6}$ originally cultured cells (stimulated PFC).

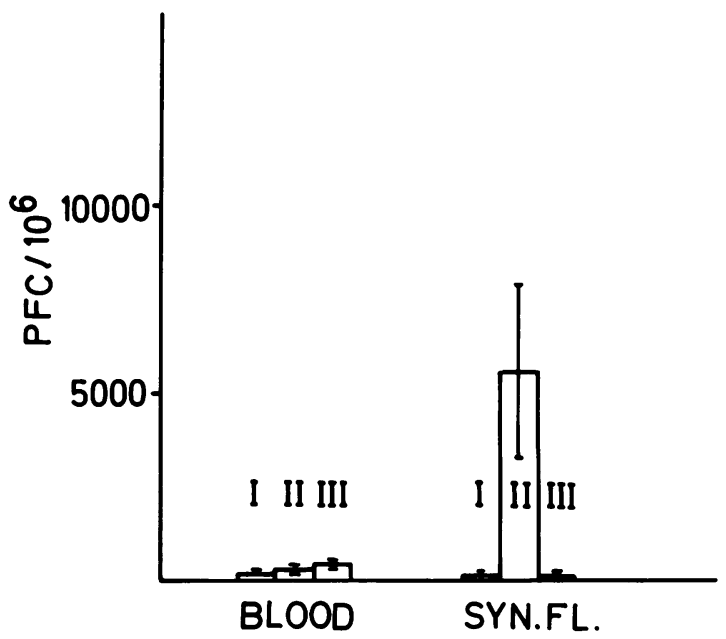

Fig. 1 Spontaneous secretion of immunoglobulins by $B M C$ and SMC. Ordinate: $P F C / 10^{6}$ live cells; $n=8$. I: IgM-PFC. II: IgG-PFC. III: IgA-PFC. 
In some experiments cells were incubated at $56^{\circ} \mathrm{C}$ for $\mathbf{1 5}$ min prior to assay for PFC activity. In additional experiments cells were incubated with 100 $\mu \mathrm{g} / \mathrm{ml}$ of cycloheximide (Sigma) for $2 \mathrm{~h}$ at $37^{\circ} \mathrm{C}$ prior to assay for PFC. Cycloheximide was present during washings and in the agar in a similar concentration.

Statistics. Data are presented as means \pm 1 SEM. The results were analysed by the 2-tailed Student's $t$-test. Values of $\mathrm{p}<0.05$ were regarded as significant.

\section{Results}

SPONTANEOUS SECRETION OF IG

The spontaneous formation of PFC by BMC was low with regard to $\mathrm{IgM}, \operatorname{IgG}$, and $\operatorname{Ig} \mathrm{A}$ (Fig. 1). Thus BMC

Table 1 Spontaneous PFC formation: influence of heating $\left(56^{\circ} \mathrm{C}\right.$ for $\left.15 \mathrm{~min}\right)$ and of treatment with cycloheximide $(100$ $\mu \mathrm{g} / \mathrm{ml}$ for 2 hours)

\begin{tabular}{|c|c|c|c|}
\hline & \multicolumn{3}{|c|}{$I g G-P F C^{1}$} \\
\hline & Expt. 1 & Expt. 2 & Expt. 3 \\
\hline SMC & 2213 & 3958 & 1869 \\
\hline SMC (heated) & 0 & 2 & 0 \\
\hline $\begin{array}{l}\text { SMC incubated } 2 \mathrm{~h}, 37^{\circ} \mathrm{C} \\
\text { SMC incubated } 2 \mathrm{~h}, 37^{\circ} \mathrm{C}\end{array}$ & 1815 & 2413 & 1208 \\
\hline + cycloheximide & 381 & 917 & 362 \\
\hline SF T-depleted cells & 2700 & 3625 & 2604 \\
\hline SF T-enriched cells & 13 & 29 & 7 \\
\hline
\end{tabular}

${ }^{1}$ Results are given as IgG-PFC/ $10^{6}$ live cells. from patients with rheumatoid arthritis were not spontaneously activated into Ig-secreting cells, which is similar to the findings in normal persons. ${ }^{16} \mathrm{By}$ contrast SMC contained a considerable number of PFC, restricted to the IgG class (Fig. 1). Thus SMC generated more IgG-PFC than did BMC $(p<0 \cdot 001)$, whereas IgM-PFC were found in similar numbers. SMC IgA-PFC were discovered to a lower degree as compared to BMC (Fig. 1) $(\mathrm{p}<0 \cdot 05)$.

To exclude the possibility that the spontaneous SMC-PFC were due to release of IgG-containing immune complexes from the cell membranes, experiments were carried out as summarised in Table 1 . SMC heated for $15 \mathrm{~min}$ at $56^{\circ} \mathrm{C}$ showed no PFC activity; hence the SMC-PFC formation requires live cells. ${ }^{18}$ Furthermore, the major part of PFC formation was inhibited by incubation with the protein synthesis inhibitor cycloheximide, supporting the assumption that SMC-IgG plaques are due to a protein-synthesising cell. ${ }^{18}$

As B lymphocytes are few in suspensions of SMC, it was of interest to ensure the B cell origin of spontaneous plaques. Synovial fluid T-enriched cells generated no PFC, whereas the capacity for spontaneous PFC formation was preserved in synovial fluid T-depleted cell suspensions (Table 1 ). In additional experiments IgG-PFC were found to a similar extent in suspensions of $\mathrm{M} \varphi$-depleted SMC, whereas less than $100 \mathrm{IgG}-\mathrm{PFC} / 10^{6}$ cells were recorded among

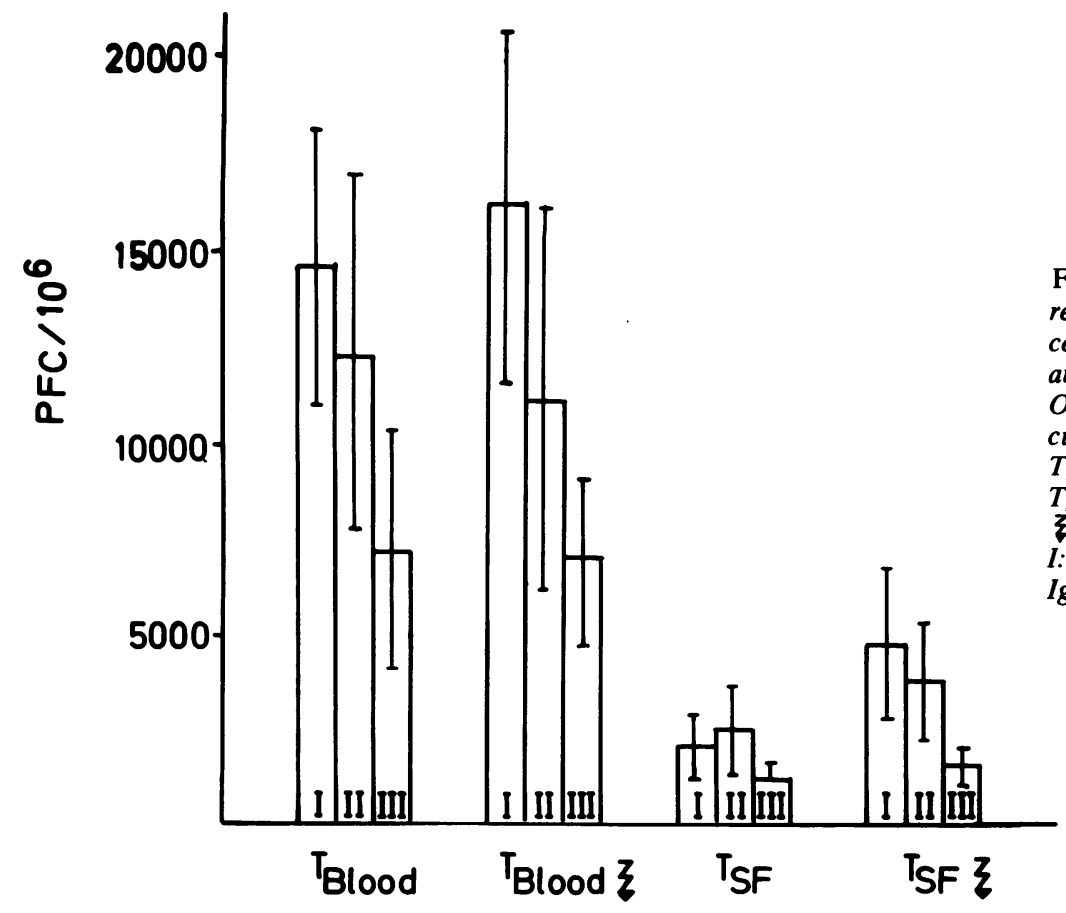

Fig. 2 PWM-induced PFC responses of $50 \%$ blood $T$-depleted cells cocultured with $50 \%$ autologous T-enriched cells; $n=8$. Ordinate: $\mathrm{PFC} / 10^{6}$ originally cultured cells.

$T_{B l o o d}: T$-enriched cells from blood. $T_{S F}$ : $T$-enriched cells from $S F$. $\xi$ denotes irradiation $(2500 \mathrm{rad})$. I: IgM-PFC. II: IgG-PFC. III: IgA-PFC. 
M $\varphi$-enriched SMC. Thus SMC-IgG plaques are caused by B lymphocytes.

POKEWEED-MITOGEN-INDUCED IG SECRETION In a previous communication it was shown that BMC from patients with rheumatoid arthritis generated considerable numbers of Ig-secreting cells in response to PWM, whereas SMC failed to do so. ${ }^{19}$ Preliminary experiments revealed that optimal PWM-PFC responses in RA patients were obtained with cocultures of $50 \%$ T-depleted and $50 \%$ T-enriched cells from the blood, in agreement with findings in normal adults ${ }^{20}$ and in neonates. ${ }^{21}$ T-depleted or T-enriched cells cultured alone failed to respond to PWM (data not shown).

First, we investigated the balance between helper and suppressor $\mathrm{T}$ cells from the blood using irradiation of T cells to eliminate suppressor activity. ${ }^{22}{ }^{23} \mathrm{As}$ outlined in Fig. 2, the PFC responses of blood T-depleted cells cocultured with blood $\mathrm{T}$ cells were similar to those obtained with irradiated $T$ cells, indicating that $T$ cells in the blood of a patient with RA do not include a significant number of $T$ lymphocytes with suppressor activities, which is in agreement with earlier findings. ${ }^{24}$ Secondly, similar experiments were performed with SF $T$ cells. Fig. 2 shows that T-enriched cells from synovial fluid supported PFC responses to a lesser degree than autologous blood $\mathrm{T}$ cells $(\mathrm{p}<0.01)$. Irradiated SF T-enriched cells yielded PWM-induced PFC responses which were higher

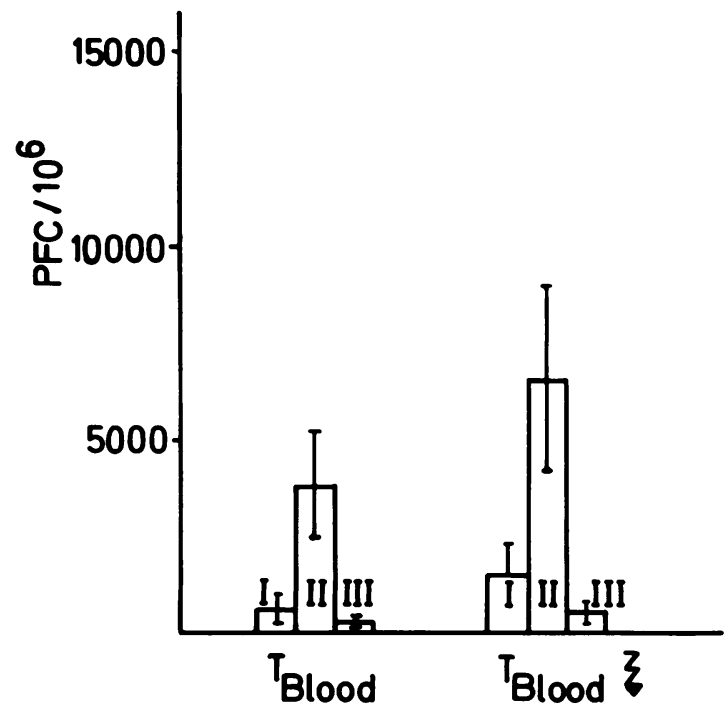

Fig. $3 P W M$-induced $P F C$ responses of $50 \% S F T$-depleted cells cocultured with $50 \%$ autologous $T$-enriched cells from the blood. Ordinate as in Fig. $2 ; n=8$.

$\xi$ denotes irradiated cells. I: IgG-PFC. II: IgM-PFC. III: IgA-PFC.
Table $2 E B V$-induced $P F C$ responses of $B M C$ and $S M C$, and of T-depleted cells from blood or synovial fluid ${ }^{1}$

\begin{tabular}{lllll}
\hline & & IgM-PFC & IgG-PFC & IgA-PFC \\
\hline BMC & Expt. 1 & 4935 & 2098 & 1921 \\
& Expt. 2 & 2578 & 1238 & 1875 \\
& Expt. 3 & 3058 & 2641 & 1238 \\
Blood & & & & \\
$\quad$ T-depleted & & & & \\
cells & Expt. 1 & 14573 & 6558 & 2857 \\
& Expt. 2 & 7992 & 3343 & 3735 \\
& Expt. 3 & 8237 & 5990 & 2796 \\
SMC & & & & \\
& Expt. 1 & 22 & 28 & 41 \\
& Expt. 2 & 0 & 19 & 21 \\
SF & Expt. 3 & 48 & 37 & 19 \\
T-depleted & & & & \\
cells & Expt. 1 & 132 & 353 & 155 \\
& Expt. 2 & 0 & 46 & 0 \\
& Expt. 3 & 26 & 56 & 31 \\
\hline
\end{tabular}

${ }^{1}$ Data are expressed as $\mathrm{PFC} 10^{6}$ originally cultured cells. Cells from 3 RA patients were investigated.

than those obtained with unirradiated cells, though the differences did not reach statistical significance.

It was of interest to investigate whether SF B cells could respond to PWM after removal of T lymphocytes. These experiments are summarised in Fig. 3. SF T-depleted cells cultured alone failed to respond to PWM (data not shown). The same cells cocultured with T-enriched cells from the blood generated a considerable number of $\mathrm{PFC}$ in the presence of PWM. As in the case of spontaneous SMC-PFC formation, the PWM-induced SF B cell response was restricted to IgG-secreting cells, whereas few IgM- or IgA-PFC were found $(p<0 \cdot 01)$. With irradiated blood $\mathrm{T}$ cells the SF B cells generated more IgG-PFC, but the difference did not reach statistical significance.

EBV-INDUCED IG-S ECRETION

Because SMC B cells were able to respond to pokeweed mitogen in the presence of blood T cells, it was of interest to evaluate the SMC responses to the direct $\mathrm{B}$ cell activator EBV. ${ }^{25} \mathrm{BMC}$ and T-depleted blood cells responded well to EBV (Table 2). By contrast, neither SMC nor SF T-depleted cells secreted Ig when challenged with EBV.

\section{Discussion}

In the present investigation the reverse haemolytic PFC assay was used to quantitate both spontaneous and in-vitro-induced Ig secretion. The spontaneous Ig secretion by RA blood lymphocytes was low. By contrast, SMC secreted Ig spontaneously, but with restriction to IgG, in accordance with the recent findings of Al-Balaghi et al. ${ }^{26}$ IgG-containing immune 
complexes are abundant in the synovial fluid of patients with $\mathrm{RA},{ }^{27}$ and these immune complexes bind to cells with Fc receptors. Experiments were performed to exclude the possibility that SMC-PFC were due to passive release of such immune complexes. First, heating of cells to $56^{\circ} \mathrm{C}$ completely abolished PFC formation. Secondly, on the addition of a protein synthesis inhibitor, cycloheximide, the majority of PFC disappeared. Thirdly, SMC-PFC formation occurred only in suspensions of SF B cells. Thus the spontaneous IgG-PFC of synovial fluid seem to be live, protein-synthesising B lymphocytes.

In an earlier report ${ }^{19}$ we found that SMC did not generate $\mathrm{PFC}$ in response to pokeweed mitogen. According to recent experiments the possibility that the low SMC responses were due to $\mathbf{M} \varphi$-mediated suppression of Ig-secreted cells has been ruled out (Petersen, unpublished data). As the low SMC-PFC formation might be due to the occurrence of synovial fluid T suppressor cells, SF SMC were depleted of T lymphocytes, and the remaining cells-that is, SF B cells plus $\mathrm{M} \varphi$ s, were cocultured with autologous $\mathrm{T}$ lymphocytes from the blood. Under these conditions synovial fluid B cells secreted Ig. Again, the secreted Ig was restricted to the IgG class. The experiments thus show that, although SF B cells spontaneously secrete IgG, probably due to activation in vivo these cells also secrete IgG in response to PWM when SF T cells are replaced with blood T cells. As SF B lymphocytes could respond to PWM under certain conditions, it was of interest to assess the SF B cell response on direct stimulation with EBV. In normal adults ${ }^{25}$ and in neonate ${ }^{25} \mathrm{EBV}$ induces a PFC response which is mainly of the IgM class. In the present study we could not generate SMC-PFC responses by means of EBV. These results disagree with earlier findings, indicating that SMC from patients with rheumatoid arthritis may transform into cell lines once they are infected with EBV. ${ }^{28}$

The recent development of hybridoma techniques has provided important tools for the characterisation of T lymphocyte subpopulations. Thus SMC from RA patients have recently been reported to contain more $\mathrm{T}$ cells with the putative suppressor phenotype than cells from blood.$^{11}$ In this report we analysed the ability of SF T cells to co-operate in the PWMinduced activation of autologous $B$ cells obtained from the blood. It was clearly shown that employment of SF T cells gave a lower B cell response than did blood $T$ cells from the same individual. As irradiation of $T$ lymphocytes abolishes their suppressive effect, ${ }^{22}{ }^{23}$ this procedure was applied to SF T cells to investigate the balance between helper and suppressor $\mathrm{T}$ functions. Irradiation of SF T cells before addition to blood B cells increased the PFC responses, although the increase was not demonstrated statisti- cally. Thus, in-vivo-activated SF T suppressor cells may be of importance for the low SMC-PFC response to pokeweed mitogen. Experiments with SF suppressor $\mathrm{T}$ cells purified by means of monoclonal antibodies are in progress in our laboratory, and these experiments may clarify the role of SF T cell subsets with regard to Ig secretion of SF B cells. Furthermore, such experiments may elucidate whether synovial fluid $B$ cells from patients with RA are amenable to suppression to the same degree as blood B cells.

This work was supported by the National Danish Association against the Rheumatic Diseases, Fonden til Lagevidenskabens Fremme, and the Ferdinand and Ellen Hindsgauls Fund. EBV was a gift from Dr Jette Hesse. The excellent technical assistance of Mrs Anne Ambjørnsen and Mrs Vita Weibull is gratefully acknowledged.

\section{References}

1 Smiley J D, Sachs C, Ziff M. In vitro synthesis of immunoglobulin by rheumatoid synovial membrane.J Clin Invest 1968; 47: 624-32.

2 Munthe E, Natvig J B. Immunoglobulin classes, subclasses and complexes of IgG rheumatoid factor in rheumatoid plasma cells. Clin Exp Immunol 1972; 12: 55-70.

3 van Boxel J A, Paget S A. Predominantly T-cell infiltrate in rheumatoid synovial membranes. $N$ Engl $J$ Med 1975; 293: 517-24.

4 Abrahamsen T G, Frøland S S, Natvig J B. In vitro mitogen stimulation of synovial fluid lymphocytes from rheumatoid arthritis and juvenile rheumatoid arthritis patients: dissociation between the responses to antigens and polyclonal mitogens. Scand J Immunol 1978; 7: 81-90.

5 Rosenberg S A, Lipsky PE. Monocyte dependence of pokeweed mitogen-induced differentiation of immunoglobulin-secreting cells from human peripheral blood mononuclear cells. $J$ Immunol 1978; 122: 926-31.

6 Gmelig-Meyling F, Waldmann T A. Human B cell activation in vitro: augmentation and suppression by monocytes of the immunoglobulin production induced by various B cell stimulants. J Immunol 1981; 126: 529-37.

7 Petersen J, Kieffer M, Lilic D, Rathlev N, Andersen V. Influence of autologous monocytes on the pokeweed mitogeninduced generation of immunoglobulin secreting cells in man. Scand J Haematol 1982; 29: 273-82.

8 Geha R. Regulation of human B cell activation. Immunol Rev 1979; 45: 275-305.

9 Frøland S S, Natvig J B, Husby G: Immunological characterization of lymphocytes in synovial fluid from patients with rheumatoid arthritis. Scand J Immunol 1973; 2: 67-73.

10 Petersen J, Andersen V, Bendixen G, et al. Functional characteristics of synovial fluid and blood mononuclear cells in rheumatoid arthritis and traumatic synovitis. Scand J Rheumatol 1982; 11: 75-80.

11 Fox R I, Fong S, Sabharwal N, Carstens S A, Kung PC, Vaughan $S \mathrm{H}$. Synovial fluid lymphocytes differ from peripheral blood lymphocytes in patients with rheumatoid arthritis. J Immunol 1982; 128: 351-4.

12 Horwitz D A, Allison A C, Ward P, Kight N. Identification of human mononuclear leucocyte populations by esterase staining. Clin Exp Immunol 1977; 30: 289-98.

13 Saxon A, Feldhaus J L, Robbins R A. Single step separation of human T and B cells using AET treated SRBC rosettes. $J$ Immunol Methods 1976; 12: 225-8. 
14 Miller G, Lisco M, Kohn M L, Stitt D. Establishment of cell lines from normal adult human blood leukocytes by exposure to Epstein-Barr virus and neutralization by human sera by exposure with Epstein-Barr virus antibody. Proc Soc Exp Biol Med 1971; 137: 1459-65.

15 Hammarström L, Bird A G, Britton S, Smith C I E. Pokeweed mitogen induced differentiation of human $B$ cells: evaluation by a protein A haemolytic plaque assay. Immunology 1979; 38: $181-9$.

16 Agger R, Petersen J, Dinesen B, Wiik A, Andersen V. Production and secretion of immunoglobulins by in vitro-activated human B lymphocytes. Allergy 1982; 37: 179-85.

17 Gronowicz E, Coutinho A, Melchers F. A plaque assay for all cells secreting Ig of a given type or class. Eur J Immunol 1979 6: 588-90.

18 Jerne N K, Henry C, Nordin A A, Fuji H, Koros A M C, Lefkovits I. Plaque forming cells: methodology and theory. Transplant Rev 1974; 18: 130-91.

19 Petersen J, Agger R, Kieffer M, Lilic D, Rathlev N, Andersen V. Immunoregulatory mechanisms evaluated by quantitation of immunoglobulin-secreting cells in man. In: Steinberg $\mathbf{C ~} \mathbf{M}$, Lefkovits I, eds. The immune system. Basel: Karger, 1981: 2: 84-90.

20 Saxon A, Stevens R H, Ashman R F. Regulation of immunoglobulin production in human peripheral blood leukocytes: cellular interactions. J Immunol 1977; 118: 1872-9.
21 Pedersen S A, Petersen J, Andersen V. Suppression of B lymphocytes in mature newborn infants. Acta Paediatr Scand 1983; 72: 441-7.

22 Fineman S M, Mudawwar F B, Geha R S. Characteristics and mechanisms of action of the concanavalin A-activated suppressor cell in man. Cell Immunol 1979; 45: 120-32.

23 Lilic D, Petersen J, Hesse J, Andersen V. Induction and abrogation of suppressor cell function in humans: effect on B cell activation by different polyclonal activators. Acta Pathol Microbiol Scand (C) 1982; 90: 251-5.

24 Janossy G, Panayi G, Duke O, Bofill M, Poulter L W, Goldstein G. Rheumatoid arthritis: a disease of $T$ lymphocyte/macrophage immunoregulation. Lancet 1981; ii: 839-42.

25 Bird A G, Britton S. A new approach to the study of human B lymphocyte function using an indirect plaque assay and a direct B cell activator. Immunol Rev 1979; 45: 41-67.

26 Al-Balaghi S, Ström H, Möller E. High incidence of spontaneous Ig-producing lymphocytes in peripheral blood and synovial fluid of patients with active seropositive rheumatoid arthritis. Scand $J$ Immunol 1982; 16: 69-76.

27 Winchester R J, Agnello V, Kunkel H G.Gamma globulin complexes in synovial fluids of patients with rheumatoid arthritis. Partial characterization and relationship to lowered complement levels. Clin Exp Immunol 1970; 6: 689-706.

28 Gillilan B C, Ford D K, Mannik M. Synthesis by an established lymphocyte cell line from a rheumatoid synovium. Arthritis Rheum 1978; 21: 330-6.

\section{Book review}

Local Injection Therapy in Rheumatic Diseases. By A. St J. Dixon and J. Graber. Pp. 181. No price given. Eular: Basle. 1983.

Apart from the clinical examination no skill is more necessary for the rheumatologist than that of local injection. The proposers of the motion at the final meeting of the Heberden Society that steroid injections did more harm than good to patients had an impossible task despite their powerful advocacy.

The production of a pocket size manual on the subject is to be warmly welcomed. The second edition of this monograph has been revised and enlarged. After a general introduction it deals with each area of the body. The indications for and the techniques of injection into each region are succinctly discussed. Excellent illustrations in the form of clinical photographs, radiographs, and diagrams clarify the procedures. No junior doctor on the rheumatological or orthopaedic service can afford to be without this book, and most consultants will be grateful for it too. We have ordered a copy for each ward in the Regional Rheumatology Centre at Harrogate.

V. WRIGHT 